\title{
Knowledge and Attitude towards Do-Not-Resuscitate Order among Nurses of a Tertiary Level Hospital
}

\author{
Asmita Shrestha and Sarala Shrestha
}

College of Nursing, Nepalese Army Institute of Health Sciences, Sanobharyang, Katmandu, Nepal

\begin{abstract}
Introduction: Knowledge regarding and attitude towards end-of-life care can shape the behaviour and actions of a health professional in provision of supportive care for the comfort of the patients as well as their family members. Very little is known about nurses' knowledge and attitude regarding do-notresuscitate (DNR) order. Therefore, the purpose of this study was to identify the knowledge of and attitude towards DNR order and relationship between knowledge and attitude towards DNR order among the nurses of a tertiary level hospital.

Methods: Descriptive correlation design was used. Convenient sampling method was used to select 70 nurses from a tertiary level hospital. Data were collected using pretested self administered structured questionnaire. Data were analysed using SPSS version 20 and analysed using descriptive and inferential statistics.

Result: Among 70 respondents, almost all (95.7\%) of the respondents had good level of knowledge, $2.9 \%$ had fair and $1.4 \%$ had poor level of knowledge. Most $(80.0 \%)$ of the respondents had positive attitude towards DNR order and $20.0 \%$ had negative attitude. There was a positive relationship between knowledge of and attitude towards DNR order $(r=0.068)$ but the relationship was statistically insignificant.

Conclusions: Based on the findings, the study concludes that nurses of tertiary level hospital have good knowledge and positive attitude towards DNR order. Likewise, knowledge regarding DNR order is related with the attitude towards DNR order and thus knowledge can be enhanced to improve the attitude towards DNR by regular in-service education.
\end{abstract}

Key words: attitude on DNR; do not resuscitate order; knowledge of DNR; nurses

Correspondence: Asmita Shrestha, College of Nursing, Nepalese Army Institute of Health Sciences, Sanobharyang, Kathmandu, Nepal. Email: asmitashrestha72@gmail.com

DOI: $10.3126 / \mathrm{mjsbh} . v 20 \mathrm{i} 2.31670$

Submitted on: 2020-10-01

Accepted on: 2021-05-31

This work is licensed under creative common license:

http://creativecommons.org/licenses/by-nc-nd/4.0/ C) MJSBH 2020 


\section{INTRODUCTION}

Cardio-pulmonary resuscitation (CPR), introduced in $1960,{ }^{1}$ is an emergency lifesaving procedure that uses chest compressions along with artificial ventilation to restore spontaneous blood circulation and breathing in a person whose heart has stopped beating. ${ }^{2}$ It has become mandatory as a life saving measure for all patients suffering from cardiac arrest. However, it is not free from complications. Some of the complications observed following CPR are fracture of ribs, liver contusion and aspiration of fluid and vomit into the lungs and injury to tissues of chest etc. ${ }^{3}$ Therefore, the use of CPR has become questionable in case of terminally ill patients without significant quality of life with added possibility of complications and burden of treatment. ${ }^{4,5}$ As a consequence, the concept of do-not-resuscitate (DNR) came into being in the care of terminally ill patients. DNR order is a medical order for health professionals to not to perform CPR on a patient when there is cardiac or pulmonary arrest. ${ }^{6}$ This order is made only after thorough consideration of the patient's situation. These situations include the patient's imminent death or in cases when CPR will only prolong patient's death, or when CPR will increase suffering and make death more painful. ${ }^{7}$ A DNR order is meant to allow natural death in the end of life care. ${ }^{8}$ Although, the concept of DNR order does not mean not to treat the terminally ill patient, this concept is often misunderstood and poorly complied by health professionals. ${ }^{9}$ So, to effectively use and prevent misuse of DNR order, health professional must be educated about DNR. ${ }^{4}$

Nursing care is directed towards meeting the comprehensive needs of patients and their families to prevent and relieve the symptoms and suffering of patients that are commonly associated with illness and dying. ${ }^{10}$ Similarly, Nepal Nursing Council, in its code of conduct spelled out that nurses should ensure that the health service consumer's physical, social and psychological needs are assessed and responded by recognising and responding compassionately to the needs of those who are in the last few days and hours of life. ${ }^{11}$

Nurses are vital to end-to-life care as they are the ones present at bedside, having the opportunity to observe behaviours and actions that are barriers to peaceful and dignified death while providing endof-life care. ${ }^{12}$ In practice, not many nurses fully understand what DNR order means and how it is applied even though the term comes very often in clinical settings. Nurses need to be aware of and have an active role in understanding and developing DNR policies, and positive attitude to provide ethically sound care and alleviating suffering of terminally ill patients. ${ }^{7,12}$ They need to put ethical principle, such as veracity and autonomy into action in providing end of life care and have to support families and patients in making a DNR decision. ${ }^{13}$ However, very few studies have been conducted regarding the nurses' understanding of DNR order. Therefore, this study was conducted to identify knowledge of and attitude towards DNR order among nurses of a tertiary level hospital. The knowledge of DNR meant possession of information related to its meaning, decision making process and provision of care, medical management and documentation. Likewise, attitude towards DNR meant attitude related to factors influencing DNR, feelings surrounding DNR status, decision making and provision of care, medical management of patient with DNR order and strategies to help deal with patient with DNR order. The findings of this study would be useful to hospital authority to understand the status of knowledge and attitude of nurses related to DNR order. This information can be useful in maintaining conducive environment and in planning in-service education on DNR order. This will facilitate in provision of supportive care to patients and their families in need of end of life care.

\section{METHODS}

This descriptive correlation study was conducted at Shree Birendra Hospital, Chhauni, Kathmandu, which is a tertiary level central hospital of the Nepalese Army. The study population consisted of nurses with certificate or bachelor level nursing qualification and working in selected units of SBH namely critical care units (ICUs), step down unit, neuro ICU, emergency unit and medical units (Medical I and Medical II). These units were selected as these are the units where death and dying are more frequently encountered by nurses. Total 80 nurses were working in these units. Out of them, 70 nurses were available during the period of 
data collection and remaining 10 were on leave. So a convenience sampling technique was used to include 70 available nurses all of whom responded to the questionnaire.

A self-administered structured questionnaire was developed to measure the study variables through literature review. Instrument consisted of three parts. The first part included questions related to demographic variables. The second part included items related to knowledge regarding DNR order and the third part included items related to attitude regarding DNR order. The instrument was pretested among eight nurses working in surgical and high care units of SBH and instrument was finalised before using it for data collection.

Research proposal and ethical clearance was obtained from the institutional research committee of Nepalese Army Institute of Health Sciences (NAIHS), College of Nursing. After obtaining written permission for data collection from SBH respondents were approached in their work units. Objectives of the research study were cleared and informed written consent was obtained. The researcher was present while the respondents filled the questionnaire to prevent data contamination through consultation. It took about 20 minutes to the respondents to fill up the questionnaire. In a day eight to 12 respondents were approached. Data was collected during the two weeks period from $2019 / 08 / 18$ to $2019 / 09 / 02$.

Collected data were coded and entered in SPSS version 20. Data were analysed using descriptive statistical methods such as frequency, percentage, mean and standard deviation. A non-parametric inferential statistics i.e. Spearman rho test was used to analyse the correlation between knowledge and attitude scores due to non-normal distribution of data. The level of significance was set at 0.05 .

\section{RESULTS}

The mean age of the respondents was 25.4 years $(\mathrm{SD}= \pm 5)$. Majority $(54.3 \%)$ of the respondents had PCL nursing qualification. Majority (62.9\%) of the respondents had up to five years of clinical experience. Highest proportion (28.6\%) of the respondents was working in ICU and majority (58.6\%) of the respondents had up to one year of work experience in the present station. Only $2.9 \%$ of the respondents had participated in conference, workshop or seminar related to DNR order. Most $(84.3 \%)$ of the respondents got information about DNR order from the clinical experience and only $27.1 \%$ of the respondents received information regarding DNR from pre-service education.

Table 1 reveals that all $(100.0 \%)$ respondents answered correctly to the statement that "DNR does not mean no-care". Almost all (94.3\%) knew correctly that CPR is not done in patients with DNR order. Almost all (90.0\%) respondents answered correctly on the statement that "the basis for DNR order is medical judgment along with patient's wish." Table 2 reveals that almost all respondents knew different care components of patients with DNR order.

Table 3 shows that almost all (97.1\%) of the respondents knew pain relieving medicines are administered to patients with DNR order as per need. Same percentage of the respondents knew that DNR order is given in written form. While $24.3 \%$ of the respondents did not know that

Table 1. Respondents' Knowledge regarding Meaning of DNR and Decision-Making Process in DNR Order $(\mathrm{N}=70)$

\begin{tabular}{l|l|l} 
Statements & Yes & No \\
& N $(\%)$ & N $(\%)$ \\
\hline
\end{tabular}

Meaning of DNR

DNR does not mean withholding all treatment*

Supportive measures are performed in the patient with DNR orders*

$54 \quad 16$

DNR does not mean "no-care"*

(77.1) (22.9)

DNR does not mean "do-not-treat"*

$(100.0)$

$68 \quad 2$

(97.1)

(2.9)

CPR is not done in patient with DNR order

$66 \quad 4$

(94.3) (5.7)

\section{Decision Making Process}

Only physician can place DNR order

$45 \quad 25$

(64.3) (35.3)

The basis for DNR order is a medical judgment along with patient's wish

$63 \quad 7$

DNR cannot be overruled

(90.0) (10.0)

$48 \quad 22$

(68.6) (31.4)

For placing DNR order, patient's wish is necessary*

$61 \quad 9$

(87.1) (12.9)

\begin{tabular}{lr|r} 
Nurse is obligated to initiate CPR if & 57 & 13
\end{tabular} there is no DNR designation 
Table 2. Respondents' Knowledge regarding Provision of Care to Patients with DNR Order $(\mathrm{N}=70)$

\begin{tabular}{|c|c|c|}
\hline Provision of Care & $\begin{array}{r}\text { Yes } \\
\mathbf{N}(\%) \\
\end{array}$ & $\begin{array}{c}\text { No } \\
\text { N }(\%) \\
\end{array}$ \\
\hline $\begin{array}{l}\text { Gastric feeding is continued even } \\
\text { if patient gets DNR order. }\end{array}$ & $\begin{array}{r}67 \\
(95.7)\end{array}$ & $\begin{array}{r}3 \\
(4.3)\end{array}$ \\
\hline $\begin{array}{l}\text { Intravenous feeding is continued in } \\
\text { patient with DNR order.* }\end{array}$ & $\begin{array}{r}66 \\
(94.3)\end{array}$ & $\begin{array}{r}4 \\
(5.7)\end{array}$ \\
\hline $\begin{array}{l}\text { Hygiene care is essential in patient } \\
\text { with DNR order. }\end{array}$ & $\begin{array}{r}66 \\
(94.3)\end{array}$ & $\begin{array}{r}4 \\
(5.7)\end{array}$ \\
\hline $\begin{array}{l}\text { If bleeding occurs in a patient with } \\
\text { DNR order, it should be controlled. }\end{array}$ & $\begin{array}{r}66 \\
(94.3)\end{array}$ & $\begin{array}{r}4 \\
(5.7)\end{array}$ \\
\hline $\begin{array}{l}\text { Oxygen administration should be } \\
\text { continued in a patient with DNR } \\
\text { order.* }\end{array}$ & $\begin{array}{r}67 \\
(95.7)\end{array}$ & $\begin{array}{r}3 \\
(4.3)\end{array}$ \\
\hline $\begin{array}{l}\text { Emotional support is required to } \\
\text { family as well as the patient with } \\
\text { DNR order. }\end{array}$ & $\begin{array}{r}69 \\
(98.6)\end{array}$ & $\begin{array}{r}1 \\
(1.4)\end{array}$ \\
\hline $\begin{array}{l}\text { In patient with DNR order, } \\
\text { positioning cannot be neglected.* }\end{array}$ & $\begin{array}{r}67 \\
(95.7)\end{array}$ & $\begin{array}{r}3 \\
(4.3)\end{array}$ \\
\hline
\end{tabular}

diagnostic investigations cannot be stopped in patient with DNR order.

Table 4 reveals that highest proportion (45.7\%) of the respondents agreed to the positive statement that medical condition of the patient should be considered in DNR order. Majority $(62.9 \%)$ of the respondents strongly agreed to the positive statement that patient with DNR order should receive humanistic care to make them safe, happy and healthy.

Table 5 reveals that majority $(57.1 \%)$ of respondents strongly agreed that patient's DNR wish must be respected. Similarly on the provision of care, the statement supportive care should be continued in patients having DNR order is strongly agreed by majority $(68.6 \%)$ of the respondents.

Table 6 reveals that the majority $(55.7 \%)$ of the respondents strongly agreed with the positive statement that monitoring of vital signs, ECG and CVP should be continued even if the patients have DNR order. Majority (58.6\%) of respondents strongly agreed to the positive statement that efforts should be made to ensure that the patient is comfortable.

Table 7 shows that almost all $(95.7 \%)$ of the respondents had good level of knowledge, 2.9\% had fair level of knowledge and $1.4 \%$ had low poor level of knowledge. Likewise, most $(80.0 \%)$ of the
Table 3. Respondents' Knowledge regarding Medical Management of Patient with DNR Order and Documentation of DNR Order $(\mathrm{N}=70)$

\begin{tabular}{|c|c|c|}
\hline Statements & $\begin{array}{l}\text { Yes } \\
\text { N }(\%) \\
\end{array}$ & $\begin{array}{c}\text { No } \\
\mathbf{N}(\%) \\
\end{array}$ \\
\hline \multicolumn{3}{|l|}{ Medical management } \\
\hline $\begin{array}{l}\text { Pain relieving medicines are } \\
\text { administered to patient with DNR } \\
\text { order as per need. }\end{array}$ & $68(97.1)$ & $\begin{array}{r}2 \\
(2.9)\end{array}$ \\
\hline $\begin{array}{l}\text { In a patient with DNR, performing } \\
\text { chest compression is withheld. }\end{array}$ & $60(85.7)$ & $\begin{array}{r}10 \\
(14.3)\end{array}$ \\
\hline $\begin{array}{l}\text { Resuscitation drugs are not } \\
\text { administered in a patient with DNR } \\
\text { order.* }\end{array}$ & $59(84.3)$ & $\begin{array}{r}11 \\
(15.7)\end{array}$ \\
\hline $\begin{array}{l}\text { In a patient with DNR order, } \\
\text { artificial airway is not inserted even } \\
\text { if respiration stops.* }\end{array}$ & $55(78.6)$ & $\begin{array}{r}15 \\
(21.4)\end{array}$ \\
\hline $\begin{array}{l}\text { In a patient with DNR order, } \\
\text { defibrillator/ cardio version is not } \\
\text { used even when heart stops } \\
\text { beating.* }\end{array}$ & $62(88.6)$ & $8(11.4)$ \\
\hline Diagnostic investigations cannot be & $53(75.7)$ & 17 \\
\hline
\end{tabular}

stopped even though patient is in

DNR order.*

\section{Documentation}

\begin{tabular}{l|l|l} 
DNR order is given in written form. & 68 (97.1) & 2 (2.9)
\end{tabular}

DNR order in oral form is illegal.* 63 (90.0) 7 (10.0)

CPR is compulsory if DNR is not in $58(82.9) \quad 12$ written form.

*Negative statement converted to positive statement

respondents had positive attitude towards DNR order. Spearman correlation analysis of knowledge and attitude scores of the respondents towards DNR order revealed a positive but weak relationship $(\mathrm{R}=$ 0.068). This relationship was statistically insignificant ( $\mathrm{p}$ value $=0.576$ which is $>0.05$ level of significance).

\section{DISCUSSION}

Discussion on nurses' knowledge regarding DNR Order:

In regards to knowledge on the meaning of DNR domain, the present study found that all (100.0\%) of the respondents had knowledge that DNR does not mean 'no-care'. This finding is somewhat similar to the finding of study conducted in Syrian Arab Republic among 140 critical care nurses, which found that $83.6 \%$ nurses knew that DNR does not mean do-not-care. ${ }^{14}$ The present study also found that almost all $(94.3 \%)$ respondents knew correctly that CPR is not done in patient with DNR order whereas the study done in 66 NICU nurses of 
Table 4. Respondents' Attitude towards DNR Order towards Factors influencing and Feeling about DNR Status $(\mathrm{N}=70)$

\begin{tabular}{|c|c|c|c|c|c|}
\hline Statements & $\begin{array}{l}\text { SA } \\
\%\end{array}$ & $\begin{array}{l}\text { A } \\
\%\end{array}$ & $\begin{array}{l}\text { UD } \\
\%\end{array}$ & $\begin{array}{l}\text { DA } \\
\%\end{array}$ & $\begin{array}{c}\text { SDA } \\
\%\end{array}$ \\
\hline \multicolumn{6}{|l|}{$\begin{array}{l}\text { Factors } \\
\text { influencing DNR } \\
\text { status }\end{array}$} \\
\hline $\begin{array}{l}\text { All cardiac patients } \\
\text { should have DNR } \\
\text { order.* }\end{array}$ & 7.1 & 7.1 & 10.0 & 54.3 & 21.4 \\
\hline $\begin{array}{l}\text { Medical condition } \\
\text { of patient should be } \\
\text { considered in DNR } \\
\text { order. }\end{array}$ & 32.9 & 45.7 & 5.7 & 12.9 & 2.9 \\
\hline $\begin{array}{l}\text { Every critically ill } \\
\text { patient should have } \\
\text { DNR order.* }\end{array}$ & 10.0 & 15.7 & 15.7 & 50.0 & 8.6 \\
\hline $\begin{array}{l}\text { End stage of cancer } \\
\text { should be a reason } \\
\text { for DNR orders. }\end{array}$ & 45.7 & 34.3 & 4.3 & 15.7 & - \\
\hline $\begin{array}{l}\text { Feeling } \\
\text { surrounding DNR } \\
\text { status }\end{array}$ & & & & & \\
\hline $\begin{array}{l}\text { It is depressing to } \\
\text { find patient in DNR } \\
\text { status.* }\end{array}$ & 8.6 & 38.6 & 31.4 & 15.7 & 5.7 \\
\hline $\begin{array}{l}\text { Powerlessness is } \\
\text { felt by the nurse } \\
\text { while looking at the } \\
\text { family of DNR } \\
\text { patient.* }\end{array}$ & 5.7 & 44.3 & 18.6 & 22.9 & 8.6 \\
\hline $\begin{array}{l}\text { Death of young } \\
\text { adult patient with } \\
\text { DNR order is } \\
\text { frustrating.* }\end{array}$ & 34.3 & 48.6 & 12.9 & 4.3 & - \\
\hline $\begin{array}{l}\text { Patients with DNR } \\
\text { order should receive } \\
\text { humanistic care to } \\
\text { make them safe, } \\
\text { happy and healthy. }\end{array}$ & 62.9 & 27.1 & 5.7 & 4.3 & - \\
\hline
\end{tabular}

an academic university hospital in the North Eastern United States found that only $24.2 \%$ nurses knew correctly the meaning of DNR as withholding CPR only. ${ }^{15}$

Regarding the nurses' knowledge about decision making process domain the present study revealed that majority $(68.6 \%)$ of the respondents had the knowledge that DNR order cannot be overruled and that most $(81.4 \%)$ of them had the knowledge that they are obligated to initiate CPR if there is no DNR designation. These findings are much higher
Table 5. Respondents' Attitude on DNR Order related to Decision Making and Provision of Care $(\mathrm{N}=70)$

\begin{tabular}{|c|c|c|c|c|c|}
\hline Statements & $\begin{array}{l}\text { SA } \\
\%\end{array}$ & A $\%$ & UD \% & $\begin{array}{l}\text { DA } \\
\%\end{array}$ & $\begin{array}{l}\text { SDA } \\
\%\end{array}$ \\
\hline \multicolumn{6}{|l|}{ Decision Making } \\
\hline $\begin{array}{l}\text { DNR status of the } \\
\text { patient should be } \\
\text { determined before } \\
\text { emergency } \\
\text { situation arise. }\end{array}$ & 52.9 & 28.6 & 7.1 & 8.6 & 2.9 \\
\hline $\begin{array}{l}\text { Obtaining the } \\
\text { patient's / family's } \\
\text { wish for DNR } \\
\text { order is the } \\
\text { physician's } \\
\text { responsibility.* }\end{array}$ & 45.7 & 37.1 & 5.7 & 8.6 & 2.9 \\
\hline $\begin{array}{l}\text { Patient's DNR wish } \\
\text { must be respected. }\end{array}$ & 57.1 & 38.6 & 1.4 & 1.4 & 1.4 \\
\hline $\begin{array}{l}\text { Even if there is a } \\
\text { minor chance of } \\
\text { prolongation of } \\
\text { life, every possible } \\
\text { procedure should } \\
\text { be applied to } \\
\text { recover the } \\
\text { patient.* }\end{array}$ & 35.7 & 44.3 & 11.4 & 5.7 & 2.9 \\
\hline $\begin{array}{l}\text { The nurse can } \\
\text { recommend DNR } \\
\text { order. }\end{array}$ & 10.0 & 32.9 & 27.1 & 21.4 & 8.6 \\
\hline Provision of Care & & & & & \\
\hline $\begin{array}{l}\text { Patients with DNR } \\
\text { should receive less } \\
\text { care than other } \\
\text { patients.* }\end{array}$ & 5.7 & 8.6 & 1.4 & 28.6 & 55.7 \\
\hline $\begin{array}{l}\text { Patient with DNR } \\
\text { order require no } \\
\text { emotional } \\
\text { support.* }\end{array}$ & 5.7 & 5.7 & 1.4 & 25.7 & 61.4 \\
\hline $\begin{array}{l}\text { Supportive care } \\
\text { should be } \\
\text { continued in } \\
\text { patients with DNR } \\
\text { order. }\end{array}$ & 68.6 & 18.6 & 4.3 & 7.1 & 1.4 \\
\hline
\end{tabular}

*Negative statement

Keys: $S A=$ Strongly Agree, $A=$ Agree, $U D=$

Undecided, $D A=$ Disagree and SDA = Strongly

than the findings of the study conducted in North Eastern United States where only $28.8 \%$ of the respondents answered DNR cannot be overruled and $57.6 \%$ answered that they are obligated to initiate CPR if there is no DNR designation. ${ }^{15}$ These variations in findings may be probably due to difference in study setting. Similarly this study revealed that $87.1 \%$ respondents stated that for placing DNR order, patient's wish is necessary. A somewhat similar finding was reported in a study 
Table 6. Respondents' Attitude on DNR Order regarding Medical Management of Patient and with DNR Order and Strategies to help them $(\mathrm{n}=70)$

\begin{tabular}{|c|c|c|c|c|c|}
\hline Statements & $\begin{array}{l}\text { SA } \\
\% \\
\end{array}$ & A $\%$ & $\begin{array}{l}\text { UD } \\
\% \\
\end{array}$ & $\begin{array}{l}\text { DA } \\
\% \\
\end{array}$ & $\begin{array}{l}\text { SDA } \\
\% \\
\end{array}$ \\
\hline $\begin{array}{l}\text { Medical } \\
\text { Management of } \\
\text { Patient with DNR } \\
\text { Order }\end{array}$ & & & & & \\
\hline $\begin{array}{l}\text { Ventilator support } \\
\text { should be continued in } \\
\text { the patient. }\end{array}$ & 38.6 & 17.1 & 12.9 & 20.0 & 11.4 \\
\hline $\begin{array}{l}\text { Analgesic therapy } \\
\text { should be initiated / } \\
\text { continued. }\end{array}$ & 51.4 & 37.1 & 7.1 & 1.4 & 2.9 \\
\hline $\begin{array}{l}\text { Total parenteral } \\
\text { nutrition should be } \\
\text { stopped.* }\end{array}$ & 2.9 & 8.6 & 7.1 & 35.7 & 45.7 \\
\hline $\begin{array}{l}\text { Antibiotics and blood } \\
\text { products should be } \\
\text { administered if patient } \\
\text { needs. }\end{array}$ & 48.6 & 40.0 & 7.1 & 2.9 & 1.4 \\
\hline $\begin{array}{l}\text { Monitoring of vital } \\
\text { signs, ECG and CVP } \\
\text { should be continued } \\
\text { even if the patient had } \\
\text { DNR order. }\end{array}$ & 55.7 & 35.7 & 2.9 & 2.9 & 2.9 \\
\hline $\begin{array}{l}\text { Specimen collection } \\
\text { for different } \\
\text { investigation is } \\
\text { appropriate for such } \\
\text { patient. }\end{array}$ & 37.1 & 38.6 & 10.0 & 11.4 & 2.9 \\
\hline $\begin{array}{l}\text { Performing diagnostic } \\
\text { imaging in patients } \\
\text { with DNR order can } \\
\text { be fruitful. }\end{array}$ & 12.9 & 38.6 & 20.0 & 17.1 & 11.4 \\
\hline $\begin{array}{l}\text { Strategies to Help } \\
\text { Deal with Patient } \\
\text { with DNR Order }\end{array}$ & & & & & \\
\hline $\begin{array}{l}\text { Efforts should be } \\
\text { made to ensure that } \\
\text { the patient is } \\
\text { comfortable. }\end{array}$ & 58.6 & 34.3 & 4.3 & 2.9 & 17.1 \\
\hline $\begin{array}{l}\text { DNR order means } \\
\text { patient is already } \\
\text { prepared to die so can } \\
\text { be left to die alone.* }\end{array}$ & 7.1 & 10.0 & 7.1 & 32.9 & 42.9 \\
\hline $\begin{array}{l}\text { Assuring patient that } \\
\text { his condition will } \\
\text { improve is essential. }\end{array}$ & 17.1 & 30.0 & 28.6 & 14.3 & 10.0 \\
\hline
\end{tabular}

conducted among 365 nurses in Addis Ababa, Ethiopia which found that $66.0 \%$ of the respondents had the knowledge that "terminally ill patients have the right to choose DNR". ${ }^{16}$
Table 7. Respondent's Level of Knowledge and Attitude regarding DNR order $(n=70)$

\begin{tabular}{|l|r|r|}
\hline Variables & Frequency & \multicolumn{1}{c|}{$\%$} \\
\hline Level of Knowledge & & \\
Poor level $(<50 \%$ score $)$ & 1 & 1.4 \\
Fair level (50-74\% score) & 2 & 2.9 \\
Good level $(\geq 75 \%$ score $)$ & 67 & 95.7 \\
Level of Attitude & & \\
Negative attitude (<60\% score) & 14 & 20.0 \\
Positive attitude $(\geq 60 \%$ score $)$ & 56 & 80.0 \\
\hline
\end{tabular}

In regards to nurses' knowledge regarding provision of care domain, the findings of the present study revealed that almost all $(98.7 \%)$ of the respondents knew that emotional support is required to families as well as the patients with DNR order. It is somewhat consistent with the finding of the study conducted in Syrian Arab Republic where $82.1 \%$ respondents knew that emotional support is essential. ${ }^{14}$

In regards to nurses' knowledge on medical management and documentation domains in the present study, $97.1 \%$ of the respondents knew pain relieving medicines are administered to patients with DNR order as per need and same percentage of the respondents knew that DNR order is given in written form. Somewhat similar results were found in the study conducted in Syrian Arab Republic where $74.6 \%$ of the respondents knew about pain medications and $94.3 \%$ knew that DNR order is in written form. ${ }^{14}$

Attitude on DNR Order:

Regarding the attitude towards factors influencing DNR order and feeling surrounding DNR status domains, $78.6 \%$ of the respondents in the present study agreed that medical condition of the patient should be considered in DNR order which is consistent with the findings of study conducted in Syrian Arab Republic. ${ }^{14}$ Similarly, the findings of the present study showed that majority $(58.6 \%)$ of respondents disagreed to the negative statement that every critically ill patient should have DNR order. Whereas the study conducted among 140 nurses in Syrian Arab Republic found that only $38.7 \%$ of the respondents disagreed with the statement. ${ }^{14}$ This discrepancy may be due to cultural differences. Less than half (47.2\%) proportion of the respondents in present study 
agreed to the negative statement that it is depressing to find patient in DNR order which is somewhat similar to the finding of the study in Syrian Arab Republic where $35.0 \%$ of respondents always found the situation as depressing. ${ }^{14}$ Similarly, $50.0 \%$ of the respondents in the present study agreed to the negative statement "powerless is felt by the nurses while looking at the family of DNR patient". This finding is higher than the finding of the study done among nurses of a university hospital in North Eastern United States where $35.7 \%$ of the respondents felt powerlessness. ${ }^{15}$

About the attitude related to decision making and provision of care domains, majority $(57.1 \%)$ of the respondents in this study strongly agreed that patient's DNR wish must be respected. Somewhat similar finding was reported in the study done in Addis Ababa, Ethiopia where $66.0 \%$ agreed that patient's right for not to resuscitate (DNR) should be respected. ${ }^{16}$ Likewise $77.1 \%$ of the respondents in the present study disagreed to the negative statement that patient with DNR order require no emotional support which is supported by the study conducted in Syrian Arab Republic where the respondents considered emotional support as essential for patient with DNR order. ${ }^{14}$

In regards to attitude related to medical management and strategies to deal with patients with DNR order domains, the majority (55.7\%) of respondents in the present study agreed that ventilator support should be continued in the patient with DNR order. This finding is lower than that in the study conducted Syrian Arab Republic where $78.6 \%$ agreed with the statement. ${ }^{14}$ In the present study, most $(81.4 \%)$ of the respondents disagreed to the negative statement that total parenteral nutrition (TPN) should be stopped in patients with DNR order which is in contrast to the findings of the study in Syrian Arab Republic where only $23.6 \%$ disagreed that TPN should be stopped. ${ }^{14}$ The disparity in findings may be due to difference in cultural background of the respondents.

In the present study majority (75.7\%) of the respondents agreed that, specimen collection for different investigation in patient with DNR order is appropriate. Likewise, $51.5 \%$ of respondents agreed that performing diagnostic imaging can be fruitful and $75.8 \%$ disagreed to the negative statement that DNR order means patient is already prepared to die. These findings are supported by the study conducted in Syrian Arab Republic where $53.6 \%$ of the respondents agreed that specimen collection for different investigation is appropriate, $51.4 \%$ of the respondents agreed that performing diagnostic imaging in patient with DNR can be fruitful and $69.7 \%$ of the respondents responded that they always make sure patient does not die alone. ${ }^{14}$

Correlation between knowledge regarding and attitude towards DNR order:

On the whole almost all (95.7\%) respondents in this study had good knowledge and most (80.0\%) had positive attitude towards DNR. This may be probably because the respondents in this study were from tertiary level hospital which is also a teaching hospital. In regards to relationship between knowledge and attitude towards DNR this study found a positive but insignificant correlation (Spearman's $\rho=0.068$ ). This finding is somewhat similar to the findings of a study done among health care workers of palliative care in Southern Phillipines which found a low positive correlation between knowledge and attitude towards palliative care with Spearman's $\rho=0.40 .{ }^{17}$

\section{CONCLUSIONS}

Based on the findings of the study it is concluded that nurses of the tertiary level hospital have good knowledge and positive attitude towards DNR order. The findings of the study might help hospital authority to incorporate such environment in the hospitals that promotes and maintains the knowledge and attitude among nurses towards end of life care and DNR order which will facilitate in quality dignified patient care. This study also recommends the need for the replication study to confirm the nature of relationship between knowledge and attitude components of DNR care. 
To cite this article: Shrestha A, Shrestha S. Knowledge and Attitude towards Do-Not-Resuscitate Order among Nurses of a Tertiary Level Hospital. MJSBH. 2021;20(2):148-55.

Conflict of Interest: None declared

\section{REFERENCES}

1. Shaw E. The history of CPR. 2019. Available from https://www.procpr.org/blog/misc/history-of-cpr

2. Bon CA, Berzon B, Schechter J, Sovari AA. Cardiopulmonary resuscitation (CPR). Sep 2020. Available from https://emedicine.medscape.com/article/1344081-overview

3. Furst J. Complications of cardiopulmonary resuscitation. Dec 2014. Available from https://www.firstaidforfree.com/ complications-of-cardiopulmonary-resuscitation-cpr/

4. Piryani RM, Piryani S. Do-Not-Resuscitate (DNR). JKMC. 2018;7(4):187-90. DOI: https://doi.org/10.3126/ jkmc.v7i4.23327

5. Bedell SE, Delbanco TL, Cook EF, Epstein FH. Survival after cardiopulmonary resuscitation in the hospital. N Engl J Med. 1983;309(10):569-76. DOI: 10.1056/NEJM198309083091001.

6. Dugdale DC. Do-not-resuscitate order. Dec 2020. Available from https://medlineplus.gov/ency/patientinstructions/ 000473.htm

7. Nepal Medical Council. Code of ethics and professional conduct-2017. 2017. Bansbari, Kathmandu. Available from: https://nmc.org.np/files/4/Code\%20of\%20Ethics_Print_version.pdf

8. Burns JP, Edwards J, Johnson J, Cassem NH, Truo RD. Do-not-resuscitate after 25 years. Crit Care Med. 2003;31(5):1543-50. DOI: 10.1097/01.CCM.0000064743.44696.49

9. Ismail M, Khashaba S, Elmusharaf K, Etman M, Hakim AK, Tierney E. Misunderstanding of the term "DNR" in a middle eastern teaching hospital. Bahrain Med Bull. 2015;37(2):1-9. DOI: 10.12816/0014417

10. American Nurses Association. Nursing care and do not resuscitate (DNR) and allow natural death (AND) decisions. 2012. Available from https://www.nursingworld.org/practice-policy/nursing-excellence/official-position-statements/ id/nursing-care-and-do-not-resuscitate-dnr-and-allow-natural-death-and-decisions/

11. Nepal Nursing Council. The Code of ethics and professional code of conduct for registered nurses and midwives in Nepal. 2019. Available from http://nnc.org.np/web-content/upload/The-code-of-ethics-programme.pdf

12. Solmasy DP, He MK, McAuley R, Ury W. Beliefs and attitudes of nurses and physicians about do not resuscitate order and who should speak to patients and families about them. Crit Care Med. 2008;36(6):1817-22. DOI: 10.1097/CCM.0b013e31817c79fe. PMID: 18496357

13. Lachman V. Do-not-resuscitate orders: Nurse's role requires moral courage. Med Surg Nurs. 2010;19(4):249-51. PMID: 20860254

14. Taha SN, Asfour HI, Attia AK. Critical care nurses' knowledge and attitudes regarding the "do not resuscitate (DNR) status". Bull High Inst Publ Health. 2010;40(3):528-63. DOI:10.21608/jhiph.2010.20619

15. Bellini S, Damato EG. Nurses' Knowledge, attitudes/beliefs, and care practices concerning do not resuscitate status for hospitalized neonates. J Obstet Gynecol Neonatal Nurs. 2009;38(2):195-205. DOI:10.1111/j. 1552-6909.2009.01009.x

16. Kassa H, Murugan R, Zewdu F, Hilu M, Woldeyohannes D. Assessment of knowledge, attitude and practice and associated factors towards palliative care among nurses working in selected hospitals, Addis Ababa, Ethiopia. BMC Palliat Care. 2014;13:6. DOI: https://doi.org/10.1186/1472-684X-13-6

17. Pasaol JC. Assessment of knowledge, attitude, practice and barriers toward palliative care among paediatric oncology health care providers in southern Philippines. Master's Thesis Submitted to the Department of Cancer Control and Population Health. Jul 2019. Available from http://www.ncc-gcsp.ac.kr/n_alumni/data/Jayson \%20Cagadas\%20Pasaol_1704101_Philippines_Thesis.pdf 